\title{
Otro Lezama Lima, el mismo
}

\section{(7oé jitrik}

Quién, en su sano juicio -salvo un duplicado de Lezama Lima como el que soñó José Saramago- se atrevería a intentar un ingreso en ese recinto cerrado, hermético, invulnerable, que es Oppiano Licario, del mismo Lezama Lima. No lo intentaré, todavía en la atmósfera de una lectura discontinua, a cada paso detenida por una verba tan incesante como compleja, si por complejo se entiende una multiplicidad de apelaciones todas significantes que parecen originarse en una erudición vertiginosa y una voluntad razonadora que pone en cuestión el tiempo del relato y aun la noción misma de relato, o la idea que tenemos de relato. Pero, precisamente por eso, no puedo dejar de merodear cerca de puertas que parecen indiferentes a cualquier llamado, esos que la crítica de diversa inspiración suele, y cree que puede, hacer. Puertas desconcertantes que no borran la idea, que en algún momento formuló el sagaz Roland Barthes, acerca de que un texto -y éste sería un excelente ejemplo- así como cualquier objeto artístico, y aun más, cualquier objeto, es análogo a una esfera, esa misteriosa forma que se brinda y se sustrae al mismo tiempo, igual por todos lados y por eso impenetrable.

Imposibilidad, pues, pero también provocación, nadie puede evitar la seducción de las esferas, desde la celeste, que inquietó a Platón, a la terrestre, que perturba el sueño de cosmógrafos y aun las que se nos ofrecen a cada rato, "¿qué hay en el interior de una nuez" clamaba un poeta, pero sobre todo los textos en particular y lo máximo, el saber: ¿o no es el "saber" mismo una esfera que no tiene principio ni fin.

Pero, así como el globo terrestre, nadie lo niega sin por eso renunciar a seguirlo llamando de ese modo, se ofrece con múltiples accidentes, puede postularse que no hay esfera perfecta, o que parece perfecta en la primera vista: en algún punto hay una irregularidad, una fisura que el ojo puede desdeñar o puede percibir: si fuera grande, como acaso una ignorancia mayúscula en el saber, el fantasma de la esfera desaparecería, lo inmediato destruiría su impenetrabilidad y también su secreto, pero si es pequeña, o mínima, convoca a una captación, "Dios está en el detalle" proclamaba Von Brentano a mediados del siglo XIX; por ese lado, exigiéndole a la mirada, esforzándola, se puede entrar y es ahí donde se establece lo que consideramos crítica. Frente a un texto, ese primer acercamiento "esferizante", y la suspensión que provoca, da lugar a dos posibles reacciones, o bien una renuncia a ver o, lo que es lo mismo, una decisión de ver lo inmediato e inscribirlo en el territorio de lo conocido, o bien, puesto que mencionamos la palabra "crítica", la apertura de un deseo de hacer algo con ese objeto esférico que se resiste y admitir las desconocidas posibilidades que ofrece lo desconocido. 
Arduo camino espera a quien opta por esta segunda vía, tanto más cuanto que hay textos que se presentan deliberadamente -las diversas vanguardias nos han acostumbrado a admitirlo y legitimarlo- como cerrados y abstrusos. Es el caso de Oppiano Licario, más extremo aún que Paradiso, texto del que en parte, porque hay nombres compartidos, es una continuación aunque tiene otro giro, va a otro lugar.

¿Cómo, pues, empezar? ¿Cuál será la fisura? No sin duda las incesante recurrencias de núcleos o conceptos o temas, el Imago por ejemplo, o las vías, iluminativa o purgativa, la fuerza, el Eros, el Aduanero Rousseau, acerca de los cuales giran los personajes y quien los mueve, un narrador que está fuera y dentro de ellos simultáneamente y que han atraído a quienes reverencian al autor y se rinden a los textos. Quizás, sin embargo, la fisura esté ahí y no se la perciba como fisura, enceguecidos por lo obvio, por ejemplo los personajes de un texto que se presenta como novela, cómo una novela no va a tener personajes, qué sería sin ellos en la idea de que se trata de novela, un tipo de texto designado de ese modo, obediente a determinada gramática y que disfruta de una posición destacada en el comercio simbólico. ¿Será ésa la fisura? ¿No es que los personajes son tan necesarios como evidentes y, en consecuencia, no se puede sino verlos y describirlos, que es lo que la crítica que se precia de tal suele hacer?

Pero, ¿qué son los personajes de una novela? Ante todo, corrientemente, nombres propios que remiten a orígenes y situaciones, pero, para nuestro desconcierto, ¿a qué origen remiten nombres como Fronesis, Ynaca Eco, Foción, Cemí, Awalobit aunque, remotamente, Mahommed y Galeb, dramatis personae de este decurso? Y, luego, en la tradicional perspectiva realista, para ser identificados como personajes indudables, suelen estar investidos de diverso y variado modo, psicológico, social, caracterológico, racial, etario, nacional, local, para actuar, en el realismo, como lo hacen las personas reales, de carne y hueso; por lo tanto, ya constituidos se entraman mediante lenguajes diferentes que corresponden o no a formas de ser, idiosincrasias, rasgos diversos y reconocibles aun en las a veces propuestas de jergas o articulaciones novedosas.

Pues aquí no, sin ser mostrados como inertes -los personajes viajan, se encuentran, fornican, se exhiben- aparecen despojados, desfamiliarizados, no se los destaca en orígenes ni en acciones, apenas en algunas rápidamente descartadas -un frustrado encuentro homosexual, un exitoso y vago encuentro heterosexual- todo lo cual aparece desplazado por esas conversaciones interminables sobre dichos asuntos, enunciaciones y correlativas réplicas en aumentativo como temas musicales que van creciendo y convocando más instrumentos, una suerte de "Bolero" de Ravel que podría no tener fin pues nunca hay acuerdos, conclusiones ni remates.

No obstante, como respondiendo de todos modos a una vaga retórica narrativa según la cual se debe personalizar a los personajes, el narrador los estudia en su entidad y en sus comportamientos y hasta los interpreta, pero lejos de hacerlo con un propósito psicoanalítico o moral o caracterológico lo hace en forma de juegos de lenguaje incesantes como resultado de lo cual quedan al mismo tiempo saturados y descarnados, en suma son propuestos como seres puramente verbales a fuerza de ser verbalizados. Un raro y coherente despojamiento oculto por un lenguaje frondoso, invasor, abrumador pero el mismo para todos, todos hablan de la misma manera, incluido el narrador: el mismo en todos y para todos y en todos los planos, en una especie de idiolecto que los unifica y hace del conjunto un clan o una secta de implícitos sobreentendidos pero que todos entienden. Se diría que es una propuesta inhumana que enfrenta las sólidamente instaladas convicciones acerca de lo que es o debe ser la narración.

Economía del exceso, pero no de referentes, bienes o privilegios, sino de palabras que se acumulan en frases complejas, saturadas, redes sintácticas o, más bien, selvas 
verbales, efecto que suele designarse como "barroco" aunque, condescendientemente, latinoamericano y, un paso más adelante, cubano. ¿Será eso la fisura que nos permitiría entrar? ¿Para ir adónde?

Desconcertante procedimiento, obliga a una lectura desviada, que va de nuestra necesidad de reconocer en un personaje una identidad a una exhibición de ideas presentadas como imágenes cuyo alcance se espiraliza hasta un punto de fuga. Podría, entonces, preguntarse por el alcance de esa operación idiomática que descansa sobre un impulso libidinal, incesante y compulsivo, no parecido a nada conocido. Y, de ahí, la pregunta, ¿a qué nos envía o conduce esta operación? Habría una primera respuesta, no muy fuerte: vanguardismo, pariente de las destructivas propuestas de Macedonio Fernández, pero, diversamente, barroquizante; dicho de otro modo, Lezama Lima como ejecutando, algo anacrónicamente, una tarea (en los límites, casi imposible) de desrrealización.

Pero seguramente hay otras fisuras, una tan amplia que no lo parece pues cubre todo el curso del texto y recibe una designación fácil de distinguir, el barroco, un estilo conocido, así sea a causa de las difuminaciones y retorcimientos expresivos, la sobrecarga de referentes, la sintaxis apresurada y la proliferación de figuras. ¿Podría, en tanto es considerado un resultado de determinadas acciones verbales, ser entendido como intencional o, al menos, una manifestación más de una estética general, de una tradicional tendencia de profundas raíces culturales, eso que se conoce como barroco? Por un lado, es cierto que lo que se llama barroco tiene lugar y fecha de nacimiento y ha tenido expresiones muy definidas en Europa así como, por arrastre, en América Latina; también que después de muchos años de dominio de una poética de linealidad expresiva y contención verbal se produjo un estallido llamado "neobarroco", donde, para recordar una diferenciación básica, hay un predominio de masa y un ocultamiento de línea, aunque, sea como fuere, no sería aventurado considerar que hay algo de deliberado en sus productos, hasta se diría de racional, sobre todo si se lo considera, en América Latina, como lo propio de una naturaleza que exige y sostiene una expresión acorde con esa imagen. Pero aquí no, la incesancia destituye toda intención, la racionalidad se refugia en el razonamiento pero se despega en la escritura.

Y, sin embargo, no se puede hablar de inconsciente o de escritura psicótica si bien todo exceso puede serlo, tampoco de intención; la sobrecarga cultural que hace marchar y detiene al mismo tiempo la marcha del texto impide tales derivas de manera que la significación que podría emerger de, al menos, esos comportamientos, lenguaje y efecto, puede situarse en un lugar casi previsible, respuesta o reacción frente a una práctica literaria impuesta que funciona como inherente a una cultura y a una historia, precolonial, directa y pretendidamente representativa, que en realidad creyendo iluminar oscurece a esa Cuba en desvelo, la Cuba que se busca y que el texto de Lezama Lima cree hallar cavando en una herencia imposible y distanciándose en un presente dudoso.

Esto no es mucho como resultado de un acercamiento a texto tan impresionante, tampoco es un acto de defensa frente a un tribunal literario que afirma ser legítimo e indiscutible; en todo caso, en su dificultad residen otras dificultades que no podrían ser afrontadas desde tan compleja trinchera. 
